AUTOR:

Cynthia Diez Pérez

ORIENTADOR:

Avaliação da mortalidade materna (1993-2002) no Hospital das Clínicas da Faculdade de Medicina de Botucatu - UNESP

Profa. Dra. IZILDINHA MAESTÁ

Resumo de tese

\author{
Maternal mortality evaluation (1993 - 2002) at Hospital das Clinicas da \\ Faculdade de Medicina de Botucatu - UNESP
}

Palavras-chave

Mortalidade materna Razão de mortalidade materna Saúde da mulher Complicações da gravidez
Dissertação apresentada ao Programa de Pós-Graduação em Ginecologia, Obstetrícia e Mastologia, Área de Concentração: Obstetrícia, da Faculdade de Medicina de Botucatu - UNESP, para a obtenção do Título de Mestre, em 24 de fevereiro de 2006.

OBJETIVO: analisar as mortes maternas ocorridas no Hospital das Clínicas da Faculdade de Medicina de Botucatu - UNESP (HC-FMB/UNESP), no período de 1993 a 2002, comparando-as com as do período de 1983-1992, estudadas em trabalho anterior. PACIENTES E MÉTODOS: estudo retrospectivo das mortes maternas registradas no Centro de Informática Médica do HC-FMB/UNESP, no período de 1993 a 2002. O protocolo clínico foi preenchido com base em prontuário médico, relatório de autópsia, anotações de enfermagem e do Serviço de Verificação de Óbitos. As mortes maternas foram classificadas em causas obstétricas diretas e indiretas. A Razão de Mortalidade Materna Hospitalar (RMMH) foi calculada pela relação entre o número de mortes maternas e o número de nascidos vivos (NV) no HC-FMB/UNESP multiplicado por 100.000. A análise estatística foi realizada utilizando-se o teste $\chi^{2}$ nas comparações $2 \times 2$. Adotou-se 5\% como limite de significância $(\rho<0,05)$. RESULTADOS: ocorreram 27 mortes maternas entre 12.680 recém-nascidos vivos, correspondendo a uma RMMH de 212,9/100.000. Houve predomínio das causas obstétricas diretas $(51,9 \%)$ decorrentes de pré-eclâmpsia $(22,2 \%)$, infecção $(11,1 \%)$, hemorragia $(11,1 \%)$ e acidente anestésico $(7,4 \%)$. As causas obstétricas indiretas foram responsáveis por $44,4 \%$ das mortes, distribuídas em cardiopatia $(14,8 \%)$ e pielonefrite (1 1, 1\%). CONCLUSÕES: embora a RMMH tenha diminuído de 422,0/100000 NV para 212,9/100.000 NV, permanece muito alta, segundo a Organização Mundial da Saúde (OMS). Tanto no período estudado quanto no período anterior, houve maior freqüência das causas obstétricas diretas.
AUTOR:

Themístocles SoARES de MAGAlHães

ORIENTADOR:

Profa. Dra. Maria Fernanda RIOS Grassi

\section{Prevalência da infecção pelo vírus linfotrópico de células T humanas (HTLV) tipo-1 em gestantes de uma cidade do Recôncavo Baiano}

\author{
Prevalence of human t-cell lymphotropic virus (HTLV) type 1 infection in pregnant \\ women from a city of the reconcavo baiano
}

Palavras-chave

HTLV $]$

HTLV 2

Gestação

Análise filogenética

Sorologia

Gravidez normal

Dissertação apresentada ao Curso de Pós-Graduação em Medicina e Saúde Humana da Escola Bahiana de Medicina e Saúde Pública para obtenção do título de Mestre em Medicina, em 9 de outubro de 2006.

OBJETIVOS: avaliar a soroprevalência de HTLV em gestantes atendidas na rede municipal de saúde da cidade de Cruz das Almas-BA e identificar as seqüências dos isolados de HTLV das gestantes infectadas. MÉTODOS: durante o período de junho a outubro de 2005, foram selecionadas 408 gestantes no ambulatório do Instituto de Perinatologia (IPER) e em sete postos da sede e da zona rural do Programa de Saúde da Família (PSF). As participantes foram submetidas a um exame clínico-obstétrico e responderam um questionário padrão com variáveis sociodemográficas (idade, escolaridade, renda familiar). Foram coletados $10 \mathrm{ml}$ de sangue em tubo contendo EDTA para realização da sorologia (Elisa). Para confirmação das amostras positivas utilizou-se o Western Blot. A região LTR total do pró-virus foi seqüenciada para a análise filogenética. RESULTADOS: a prevalência da infecção pelo HTLV-1 foi de 0,98\% (4/408). Nenhuma gestante estava infectada pelo HTLV-2. Não houve diferença estatística entre a média de idade, renda familiar e escolaridade entre as gestantes infectadas e não infectadas. Todos os isolados agruparam-se no subtipo HTLV- la, dentro do grupamento Latino Americano. CONCLUSÃO: a prevalência da infecção pelo HTLV-1 em gestantes de Cruz das Almas é semelhante à prevalência descrita em gestantes de Salvador. Os isolados de HTLV-1 encontrados pertencem ao subtipo cosmopolita (a) do subgrupo transcontinental (A) do cluster da América Latina. 